\title{
Diatomaceous earth application to improve shrimp aquaculture: growth performance and proximate composition of Penaeus vannamei juveniles reared in biofloc at two salinities
}

\author{
Emmanuel Martínez-Montaño ${ }^{1,2}$, Gustavo A. Rodríguez-Montes de Oca ${ }^{3}$, José C. Román-Reyes ${ }^{3}$ \\ Rosario Pacheco-Marges ${ }^{3}$, Alejandro Llanos ${ }^{4} \&$ Isaura Bañuelos-Vargas ${ }^{3}$ \\ ${ }^{1}$ Maestría en Ciencias Aplicadas, Unidad Académica de Ingeniería en Biotecnología \\ Universidad Politécnica de Sinaloa, Mazatlán, Sinaloa, México \\ ${ }^{2}$ Cátedras CONACYT, Consejo Nacional de Ciencia y Tecnología, Ciudad de México, México \\ ${ }^{3}$ Facultad de Ciencias del Mar, Universidad Autónoma de Sinaloa, Mazatlán, Sinaloa, México \\ ${ }^{4}$ Diatomix S. de R.L. de C.V., Zapopan, Jalisco, México \\ Corresponding author: Isaura Bañuelos-Vargas (dra.mariabanuelos@uas.edu.mx)
}

\begin{abstract}
Silicon dioxide has been used in aquaculture to increase the abundance of diatoms; however, its relationship with water quality or productive performance has not been investigated. Our study evaluated the effect of diatomite on water quality, growth performance and proximate composition of Penaeus vannamei reared in seawater (E1) and brackish water (E2) with biofloc. Two independent experiments (E1 and E2), each one with three treatments with biofloc were evaluated: treatments D with a weekly addition of diatomite $(10 \mathrm{~g}$ $\mathrm{m}^{-3}$ ); the treatments D plus a continuous inoculum of diatom Chaetoceros muelleri (DD); and only biofloc like control, for E1 was used post-larvae with an initial body weight (IBW) of $0.0075 \mathrm{~g}$; while in E2 was used juvenile with an IBW of $1.42 \mathrm{~g}$. After seven weeks in E1, non-significant differences were registered in survival, weight gain (WG), specific growth rate (SGR) and feeding conversion rate (FCR) between DD treatment and control. However, in E2, the treatment D showed significantly higher WG $(9.83 \mathrm{~g})$ and SGR $\left(4.25 \% \mathrm{~d}^{-1}\right)$ compared to control (7.64 $\mathrm{g}$ and $3.86 \% \mathrm{~d}^{-1}$, respectively). Conversely, the FCR was lower in treatment D (1.16) compared to control (1.49). Non-significant differences were recorded in the proximate composition for shrimp, periphyton, and biofloc, among treatments in both experiments. Levels of nitrogenous wastes were similar among treatments. While in E2, the concentration of settleable solids was significantly higher in treatments with diatomite compared to control. Our results recommend the use of diatomite to improve the growth performance of shrimps cultured in brackish water with biofloc.
\end{abstract}

Keywords: Penaeus vannamei; diatomite; biofloc; silicon; brackish water; white shrimp

\section{INTRODUCTION}

The whiteleg shrimp Penaeus vannamei has great importance worldwide, given its high demand and wholesale prices, in addition to being a euryhaline species that exhibits a fast growth rate and grows well in coastal and inland aquaculture systems. A controversial aspect in its cultivation is that it requires high water exchange to maintain an acceptable water quality, which likely impacts the trophic status of adjacent aquatic environments, besides the potential entry into farming systems of vector organisms of pa- thogens and predators (Hargreaves, 2013). The above has driven the need to develop more sustainable culture alternatives, including the use of systems with minimum or zero water exchange. One of the strategies used at a commercial level is the implementation of biofloc technology (BFT) as an eco-friendly technology employed for intensive cultivation of shrimp (Kumar et al., 2018). This culture system involves the development of communities of microorganisms, mainly bacteria and microalgae, as well as a heterogeneous matrix of organic detritus, exoskeletons, invertebrates and numerous microscopic organisms in 
a heterotroph ecosystem (Emerenciano et al., 2013a; Ponce-Palafox et al., 2019). The BFT produces positive effects, like the removal of nitrogen waste, organic matter degradation and an improved physiological condition of organisms due to their potential probiotic and prebiotic effects; besides, these provide a supplementary protein source (Martínez-Córdova et $a l ., 2015)$. There are abundant literature reports on the benefits of biofloc on shrimp post-larvae and juveniles cultured in waters with salinities above $27 \mathrm{~g} \mathrm{~L}^{-1}$ (Xu et al., 2012; Emerenciano et al., 2013a; Schveitzer et al., 2013; Khatoon et al., 2016). However, the few studies with BFT in fresh or brackish water (0-18 $\left.\mathrm{g} \mathrm{L}^{-1}\right)$ have shown conflicting results regarding the growth and survival of cultured shrimp under these conditions (Ray et al., 2011; Maicá et al., 2014; Moreno-Arias et al., 2016; Ray \& Lotz, 2017). On the other hand, recent studies indicate that white shrimp cultured in biofloc increases its growth with increased salinity, where the best response was obtained at $25.5 \mathrm{~g} \mathrm{~L}^{-1}$ (Ponce-Palafox et al., 2019).

The development of BFT systems has focused on maintaining a proper balance of the carbon/nitrogen $(\mathrm{C}: \mathrm{N})$ ratio in water as an essential condition for the development of heterotrophic bacterial communities. However, it is known that microalgae are the second largest group growing in these farming systems, playing a key role in the maintenance of water quality of cultures and as a nutritional source (Ekasari et al., 2014; Xu et al., 2016). Becerra-Dorame et al. (2012) indicate that autotrophic BFT systems (dominated by microalgae) contain higher lipid levels relative to heterotrophic systems (dominated by bacteria), which can influence growth and feed efficiency of the cultured organisms. Previously, it has been reported that the addition of sodium silicates to freshwater BFT cultures leads to higher abundances of various groups of diatoms (Widanarni et al., 2012). Hence, increased lipid content in BFT in these systems may be related to higher microalgal biomass in the farming system. However, the BFT is still in its infant stage, since a lot more research is needed to optimize the system (Bossier \& Ekasari, 2017).

The use of zeolites (silicate minerals extracted from either natural deposits or synthesis) has been done to stimulate the growth of microalgae, particularly diatoms (Nieves et al., 2000); however, due to the differences in the physical and chemical characteristics between sources, the effects of zeolites on water quality and growth performance in shrimp cultures are contradictory (Silapajarn et al., 2006; Zhou \& Boyd, 2014). There are other siliceous products, such as diatomaceous earth (diatomite), for which no in-depth studies have been conducted to date to assess its effect on the production parameters of cultured shrimps. Also, shrimp culture is carried out under conditions of variable salinity, so it is necessary to know if this influences the effects of diatomite. So, the present study aimed to evaluate the effects of diatomite on water quality, growth performance and proximal composition of shrimp $P$. vannamei cultured on seawater and brackish water with biofloc.

\section{MATERIALS AND METHODS}

\section{Facilities, source of shrimp and experimental proce- dure}

Shrimp Penaeus vannamei used in the present study was provided by Laboratorio de Producción Comercial Proveedora de Larvas S.A. de C.V. (FITMAR, Mazatlán, Sinaloa). Bioassays were carried out in the Faculty of Marine Sciences at the Autonomous University of Sinaloa, Mazatlán, Sinaloa, Mexico.

Two independent bioassays (E1 and E2) were conducted with the biofloc technology (BFT). E1 was done in seawater (mean salinity $32 \mathrm{~g} \mathrm{~L}^{-1}$ ) from Mazatlán Bay. E2 realized with brackish water (mean salinity $14 \mathrm{~g} \mathrm{~L}^{-1}$ ). Each one was run independently in 12 outdoor experimental units (tanks). Each bioassay evaluated the follow: treatment D32 and D14 (for E1 and $\mathrm{E} 2$, respectively) consisted of a weekly addition of $10 \mathrm{~g} \mathrm{~m}^{-3}$ diatomaceous earth (Diatomix ${ }^{\mathrm{TM}}$, Diatomix S. de R.L. de C.V.); treatments DD32 and DD14 (E1 and $\mathrm{E} 2$, respectively) consisted of the weekly addition of diatomaceous earth plus a $20 \mathrm{~L}$ inoculum of the diatom Chaetoceros muelleri (at 800,000 cells $\mathrm{mL}^{-1}$ ) every third day, from the beginning to the end of each experiment. Each bioassay was carry on one control (Control-32 and Control-14 for E1 and E2, respectively) with BFT without diatomite and diatom inoculum. All treatments and controls were carried out in triplicate. During each bioassay, shrimps were fed a commercial diet with $35 \%$ protein and $14 \%$ lipids (Silver Cup ${ }^{\mathrm{TM}}$, El Pedregal S.A. de CV) three times a day.

For both experiments, seawater from the Mazatlán bay was used, which was filtered through a $10 \mu \mathrm{m}$ mesh before being poured into the experimental units. Salinity was measured every third day and, if necessary, was adjusted to the target level with fresh water. Experimental units consisted of nine cylinderconical tanks of $1.7 \mathrm{~m}^{3}$. At the bottom of each experimental unit, a porous tube (Aero-Tube ${ }^{\mathrm{TM}}$ ) was installed to provide aeration to water at an oxygen saturation level and keep solids in suspension. Tanks were covered with a mesh and transparent plastic film to reduce water loss by evaporation and maintain a stable temperature. 


\section{Experiment 1 (E1): seawater with a salinity of $32 \mathrm{~g}$ $\mathbf{L}^{-1}$}

E1 was carried out from May to June 2017, with duration of 47 days. Seven days before seeding the organisms to promote biofloc development in all experimental units, tanks were fertilized using a mixture of urea $\left(1 \mathrm{~g} \mathrm{~m}^{-3}\right)$, phosphoric acid $\left(1.5 \mathrm{~g} \mathrm{~m}^{-3}\right)$ and wheat brand $\left(20 \mathrm{~g} \mathrm{~m}^{-3}\right)$ for three days, along $25 \mathrm{~g}$ $\mathrm{m}^{-3}$ of ground commercial feed and sugarcane molasses until shrimp were stocked: afterward to maintain a $\mathrm{C}: \mathrm{N}$ ratio 20:1, sugarcane molasses and wheat bran as a carbon source, were added daily after feed addition in a ratio of 50:50 adjusted for moisture content for both ingredients according to the procedure described by Emerenciano et al. (2013b).

Throughout the culture, a mixture of molasses and cornflour were pre-hydrated for $24 \mathrm{~h}$ and daily added to each experimental unit. Afterward, shrimp (batch 1) were stocked at 200 post-larvae $\mathrm{m}^{-3}$ (PL19, the initial body weight of $0.0075 \mathrm{~g}$ ) in each experimental unit. The feeding rate was $10 \%$ of the estimated biomass for each tank until shrimp reached an average weight of 1 $\mathrm{g}$; then, it was adjusted to $5 \%$ for the rest of the experiment. Calculations were carried out through weekly weight biometrics, for which the wet body weight $( \pm 0.01 \mathrm{~g})$ of a random 20 -shrimp sample per experimental unit was recorded.

\section{Experiment 2 (E2): brackish water with a salinity of $14 \mathrm{~g} \mathrm{~L}^{-1}$}

E2 was carried out from July to August 2017, with duration of 49 experimental days. Before starting this bioassay, water containing biofloc from the three control experimental units from $\mathrm{E} 1$ was pumped into a single $9 \mathrm{~m}^{-3}$ tank and salinity adjusted to $14 \mathrm{~g} \mathrm{~L}^{-1}$ adding $50 \mu \mathrm{m}$ filtered fresh water. This biofloc tank was used to rear a new stock (batch 2) of shrimp (initial body weight of $0.087 \mathrm{~g}$ ) until organisms reached an average weight of $1.42 \pm 0.45 \mathrm{~g}$. Subsequently, biofloc was distributed across the different experimental tanks in E2 and shrimps were stocked at 133 org m ${ }^{-3}$ (initial average biomass of $284 \mathrm{~g} \mathrm{~m}^{-3}$ ). Weekly feeding rates and biometrics were measured following the methods described for E1. Biofloc was maintained adjusting C:N ratio 20:1 in tanks with molasses and cornflour as described for E1.

At the end of each experiment (E1 and E2), the total biomass and number of organisms per tank were recorded. One sample of whole-body shrimp, biofloc (biofloc dry weight in $\mathrm{mg} \mathrm{L}^{-1}$ was measured after filtration using a fiberglass filter with $50 \mu \mathrm{m}$ pore size) and periphyton (attached to tank walls) were collected from each experimental unit and stored at $-20^{\circ} \mathrm{C}$ for subsequent proximal analysis.

\section{Determination of water quality parameters}

Temperature $\left(\mathrm{T},{ }^{\circ} \mathrm{C}\right)$, dissolved oxygen $\left(\mathrm{DO}, \mathrm{mg} \mathrm{L}^{-1}\right)$ (YSI Inc., Yellow Spring, OH, USA) and salinity $\left(\mathrm{g} \mathrm{L}^{-1}\right)$ (refractometer ATAGO, Tokyo, Japan) were measured daily. Weekly water samples were collected from each experimental tank (before diatomite was added) and tested for settleable solids $\left(\mathrm{mL} \mathrm{L}^{-1}\right)$ with $1 \mathrm{~L}$ Imhoff cones (Avnimelech, 2007), $\mathrm{pH}$ (potentiometer Hanna Instruments Inc., USA), total alkalinity $\left(\mathrm{CaCO}_{3}, \mathrm{mg} \mathrm{L}^{-1}\right)$, total ammonia nitrogen (TAN, mg L $\mathrm{L}^{-1}$ ), nitrates $\left(\mathrm{NO}_{3}-\right.$ $\left.\mathrm{N}, \mathrm{mg} \mathrm{L}^{-1}\right)$, nitrites $\left(\mathrm{NO}_{2}-\mathrm{N}, \mathrm{mg} \mathrm{L}^{-1}\right)$, phosphate $\left(\mathrm{PO}_{4}\right.$, $\left.m g \mathrm{~L}^{-1}\right)$ and silicates $\left(\mathrm{SiO}_{4}, \mathrm{mg} \mathrm{L}^{-1}\right)$ using commercial YSI kits and a YSI 9300 photometric analyzer.

\section{Growth performance}

The survival rate, weight gain, individual weight gain (WG), specific growth rate (SGR) and feed conversion rate (FCR) were calculated using the following equations (Guillaume et al., 2004):

Weight gain $(\mathrm{WG}, \mathrm{g})=$ final weight - initial weight

SGR $\left(\% \mathrm{~d}^{-1}\right)=[(\ln$ final weight $-\ln$ initial weight $) /$ day of the experiment] $\times 100$

Final biomass $(\mathrm{g})=$ final individual weight $\times$ final shrimp number

FCR $=$ Feed added $/$ wet body weight gained

Survival $(\%)=($ final shrimp number $/$ initial shrimp number) $\times 100$

\section{Proximate analyses}

Moisture, ash and crude protein content in whole-body shrimp, biofloc and periphyton were determined according to standard AOAC (2000) methods. Crude lipid content was determined with the modified method of Folch et al. (1957), using a 2:1 (v:v) chloroform: methanol mixture.

\section{Statistical analysis}

The results are shown as mean \pm standard deviation. All percentage data were transformed to arcsine of the square root before statistical analysis in order to meet the normality and homoscedasticity assumptions (Zar, 1999). The normality of distributions and homogeneity of variances were tested using the KolmogorovSmirnov test and Levene test, respectively. Differences between treatments were tested using one-way ANOVA and Tukey's multiple comparison tests. Where the assumption of normality was not satisfied even after data transformation, a Kruskal-Wallis nonparametric test was performed. The level of significant difference was set at $P<0.05$. The software SigmaPlot 10.0 was used for the statistical analysis of all data. 


\section{RESULTS}

\section{Physical and chemical parameters of water in experimental units}

Mean values for physical and chemical variables of water in E1 and E2 experiments are shown in Tables 1 and 2 , respectively. These analyses indicated that $\mathrm{T}$, $\mathrm{DO}, \mathrm{pH}$, salinity and alkalinity were not significantly different $(P>0.05)$ between treatments in each bioassay; however, the final $\mathrm{PO}_{4}$ concentration in E1 was significantly lower $(P=0.041)$ when diatomite was added in treatments D32 and DD32 (1.66 and $1.53 \mathrm{mg}$ $\mathrm{L}^{-1}$, respectively) compared to Control-32 $\left(2.45 \mathrm{mg} \mathrm{L}^{-1}\right)$.

Furthermore, results show that average TAN and $\mathrm{NO}_{2}-\mathrm{N}$ were similar in both experiments, with no significant differences between treatments (Fig. 1). The

Table 1. Water quality parameters in tanks of postlarvae of Penaeus vannamei cultivated in seawater $\left(32 \mathrm{~g} \mathrm{~L}^{-1}\right)$ with biofloc and diatomite. Data are means values \pm standard deviation. Control-32: biofloc in marine water; D32: biofloc with the addition of diatomite; DD32: biofloc with the addition of diatomite and diatoms Chaetoceros muelleri. DO mean dissolved oxygen, $\mathrm{PO}_{4}$ mean phosphates and $\mathrm{CaCO} 3$ mean alkalinity. Values in the same row with different letters are significantly different $(P<0.05)$.

\begin{tabular}{lccc}
\hline Parameter & Control-32 & D32 & DD32 \\
\hline Temperature $\left({ }^{\circ} \mathrm{C}\right)$ & $28.7 \pm 0.8$ & $28.5 \pm 0.9$ & $28.7 \pm 0.9$ \\
$\mathrm{DO}\left(\mathrm{mg} \mathrm{L}^{-1}\right)$ & $6.5 \pm 0.9$ & $6.3 \pm 0.8$ & $6.3 \pm 0.8$ \\
$\mathrm{pH}$ & $8.1 \pm 0.2$ & $8.2 \pm 0.1$ & $8.2 \pm 0.1$ \\
Salinity $\left(\mathrm{g} \mathrm{L}^{-1}\right)$ & $32.8 \pm 1.8$ & $32.7 \pm 1.5$ & $32.7 \pm 1.4$ \\
$\mathrm{PO}_{4}\left(\mathrm{mg} \mathrm{L}^{-1}\right)$ & $2.45 \pm 0.70^{\mathrm{a}}$ & $1.66 \pm 0.89^{\mathrm{b}}$ & $1.53 \pm 0.29^{\mathrm{b}}$ \\
$\mathrm{CaCO}_{3}\left(\mathrm{mg} \mathrm{L}^{-1}\right)$ & $147 \pm 15$ & $145 \pm 27$ & $162 \pm 9$ \\
\hline
\end{tabular}

Table 2. Water quality parameters in tanks of juvenile of Penaeus vannamei cultivated in brackish water $\left(14 \mathrm{~g} \mathrm{~L}^{-1}\right)$ with biofloc and diatomite. Data are means values \pm standard deviation. Control-14: biofloc in brackish water; D14: biofloc with the addition of diatomite; DD14: biofloc with the addition of diatomite and diatoms Chaetoceros muelleri. DO mean dissolved oxygen, $\mathrm{PO}_{4}$ mean phosphates and $\mathrm{CaCO}_{3}$ mean alkalinity. Values in the same row for every experiment with different letters are significantly different $(P<0.05)$.

\begin{tabular}{lccc}
\hline Parameter & Control-14 & D14 & DD14 \\
\hline Temperature $\left({ }^{\circ} \mathrm{C}\right)$ & $30.2 \pm 1.2$ & $30.5 \pm 1.3$ & $30.3 \pm 1.3$ \\
$\mathrm{DO}\left(\mathrm{mg} \mathrm{L}^{-1}\right)$ & $6.4 \pm 0.6$ & $6.4 \pm 0.5$ & $6.4 \pm 0.6$ \\
$\mathrm{pH}$ & $8.2 \pm 0.3$ & $8.1 \pm 0.3$ & $8.2 \pm 0.2$ \\
Salinity $\left(\mathrm{g} \mathrm{L}^{-1}\right)$ & $14.1 \pm 1.2$ & $14.0 \pm 1.4$ & $14.7 \pm 1.1$ \\
$\mathrm{PO}_{4}\left(\mathrm{mg} \mathrm{L}^{-1}\right)$ & $1.70 \pm 0.57$ & $1.50 \pm 0.36$ & $1.85 \pm 0.65$ \\
$\mathrm{CaCO}_{3}\left(\mathrm{mg} \mathrm{L}^{-1}\right)$ & $128 \pm 14$ & $119 \pm 6$ & $130 \pm 13$ \\
\hline
\end{tabular}

highest $\mathrm{NO}_{3}-\mathrm{N}$ concentrations $\left(14.2 \mathrm{mg} \mathrm{L}^{-1}\right)$ were observed in E2 after six weeks of culture, but nonsignificant differences between treatments were observed.

Otherwise, in E1 was observed the highest $\mathrm{SiO}_{4}$ level, which occurred in DD32 at the fourth week (9.5 $\left.\pm 0.7 \mathrm{mg} \mathrm{L}^{-1}\right)$, then decreasing abruptly in the next week (Fig. 2). Also, the treatment D32 showed significantly higher values of $\mathrm{SiO}_{4}$ compared to Control-32 from week 5 to the end of the experiment. In E2, a trend to decreasing $\mathrm{SiO}_{4}$ levels with time was noted in treatment DD14, while Control-14 and D14 showed an increasing trend. In no case, these trends reached statistical significance between them (Fig. 2).

In E1, settleable solids showed an increasing trend in all treatments until week 5, with the highest values found in DD32 (until $18 \mathrm{~mL} \mathrm{~L}^{-1}$ ) for the duration of this experiment (Fig. 3). In E2, the highest settleable solids levels were observed in treatments D14 and DD14 (8.2 \pm 3.8 and $9.8 \pm 2.0 \mathrm{~mL} \mathrm{~L}^{-1}$, respectively), which were significantly higher $(P<0.05)$ versus Control-14 $(2.8 \pm$ $\left.2.67 \mathrm{~mL} \mathrm{~L}^{-1}\right)$ at the end of week 6 .

\section{Growth parameters}

In the experiment $\mathrm{E} 1$, post-larvae $(0.0075 \mathrm{~g}$ initial (IBW) showed survival above $85 \%$ after 47 days of culture, with no significant differences between treatments (Table 3). Likewise, Control-32 and DD32 treatment showed no significant differences in WG, SGR and final biomass; however, both treatments showed significantly higher final biomass (903 and $1,175 \mathrm{~g}$, respectively) compared to treatment D32 (701 $\mathrm{g})$. On the other hand, the FCR, with average values of 1.01 to 1.06 , did not show significant differences between treatments in experiment E1.

At the end of the experiment with brackish water (E2), the D14 treatment showed higher values in the final survival rate $(90 \pm 7.6 \%)$ and Control-14 the low values $(81.3 \pm 14.3 \%)$, but with no statistical differences between them (Table 4). However, the final weight, WG, SGR and final biomass were all significantly higher in treatment D14 compared to ontrol-14 (Table 4). In contrast, the FCR was significantly higher in Control-14 (1.49 \pm 0.11$)$ relative to D14 (1.16 \pm 0.09$)$.

\section{Proximate composition of periphyton, biofloc, and shrimp}

In E1, the proximate composition (wet weight, \%) of periphyton and whole-body shrimp did not significantly differ between treatments (Table 5); however, the crude protein content was significantly higher in treatments DD32 (3.40 $\pm 0.53 \%)$ and Control-32 (3.56 

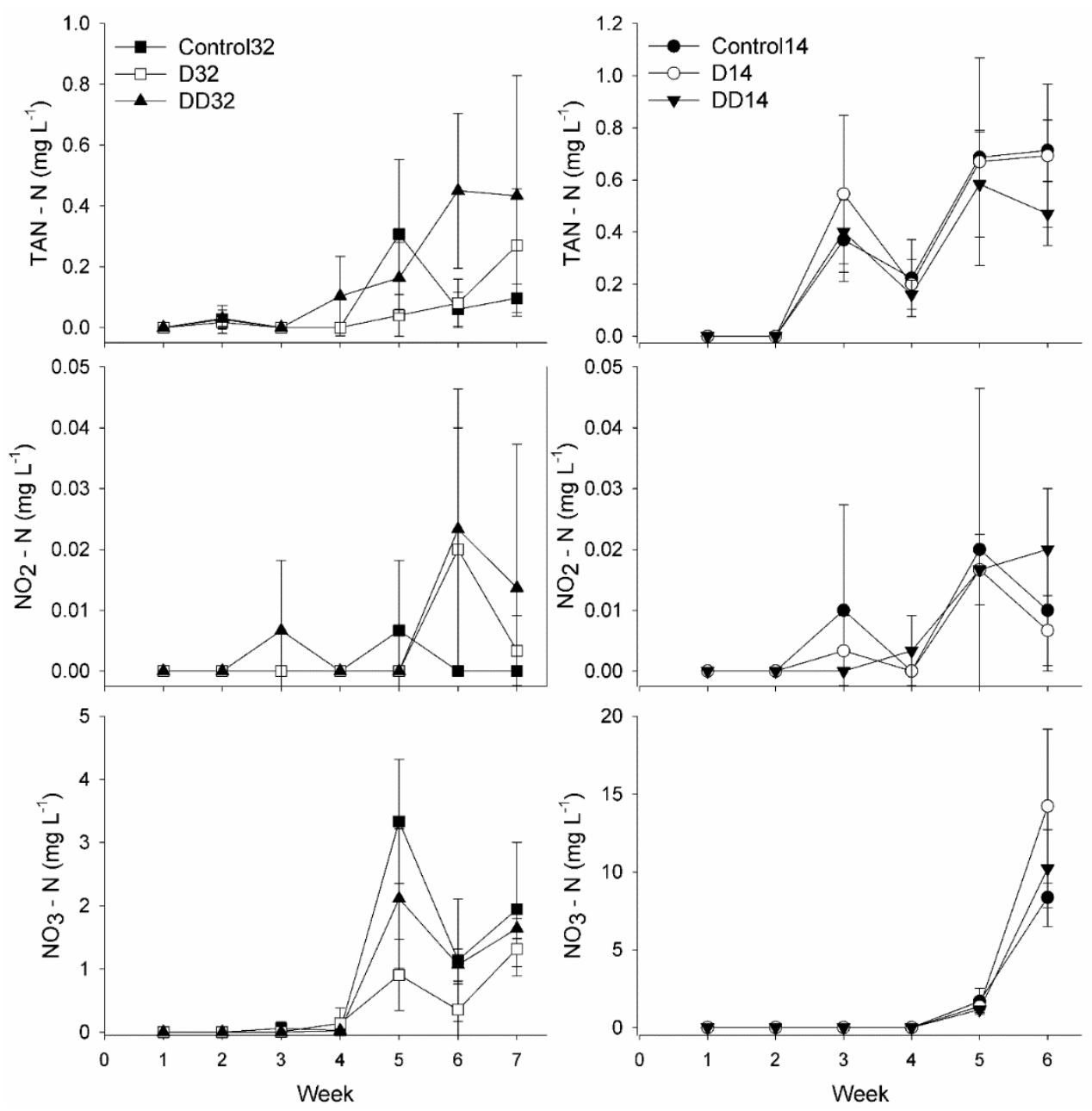

Figure 1. Mean variations of total ammonia nitrogen (TAN), nitrites $\left(\mathrm{NO}_{2}-\mathrm{N}\right)$, and nitrates $\left(\mathrm{NO}_{3}-\mathrm{N}\right)$ in different treatments at $32(\mathrm{E} 1)$ and $14(\mathrm{E} 2) \mathrm{g} \mathrm{L}^{-1}$ salinities conditions.

$\pm 0.14 \%)$ compared to D32 (2.29 $\pm 0.24 \%)$ in the biofloc of this experiment.

In E2 was found significantly higher ash content in D14 and DD14 from periphyton (4.43 and $4.22 \%$, respectively) and biofloc (4.26 and $4.3 \%$, respectively) compared to Control-14 (2.15 and $2.25 \%$ for periphyton and biofloc, respectively) (Table 6). However, no significant differences between treatments were found in terms of moisture, protein and lipid content in periphyton and biofloc. The proximate composition of whole-body shrimp showed no significant differences across treatments in E2.

\section{DISCUSSION}

The environmental parameters of water in both experiments conducted in this study were within the recommended ranges for Penaeus vannamei postlarvae and juveniles (Da Silva et al., 2013; Maica et al.,
2014), which indicate a proper management of water quality, a key aspect in farming systems with minimum or no water exchange.

The intensive white shrimp production processes in marine systems with biofloc showed significant increases in $\mathrm{PO}_{4}$ that have related to the accumulation of excreta and decomposition of non-consumed food (Da Silva et al., 2013). In our experiment with seawater, the addition of diatomite was related to a decrease in $\mathrm{PO}_{4}$ levels. Siliceous compounds such as diatomite and zeolites have been extensively used to remove dissolved $\mathrm{PO}_{4}$ through adsorption and ion exchange (Xie et al., 2014). Also, the decrease in $\mathrm{PO}_{4}$ levels observed in the bioassay with biofloc in seawater may be related to the effect of diatomite on the growth of microalgae, which are effective in removing and recycling nitrogen and $\mathrm{PO}_{4}$ compounds $P$. vannamei cultures (Magnotti et al., 2016; Marinho et al., 2017). This is because microalgae are the second major group 

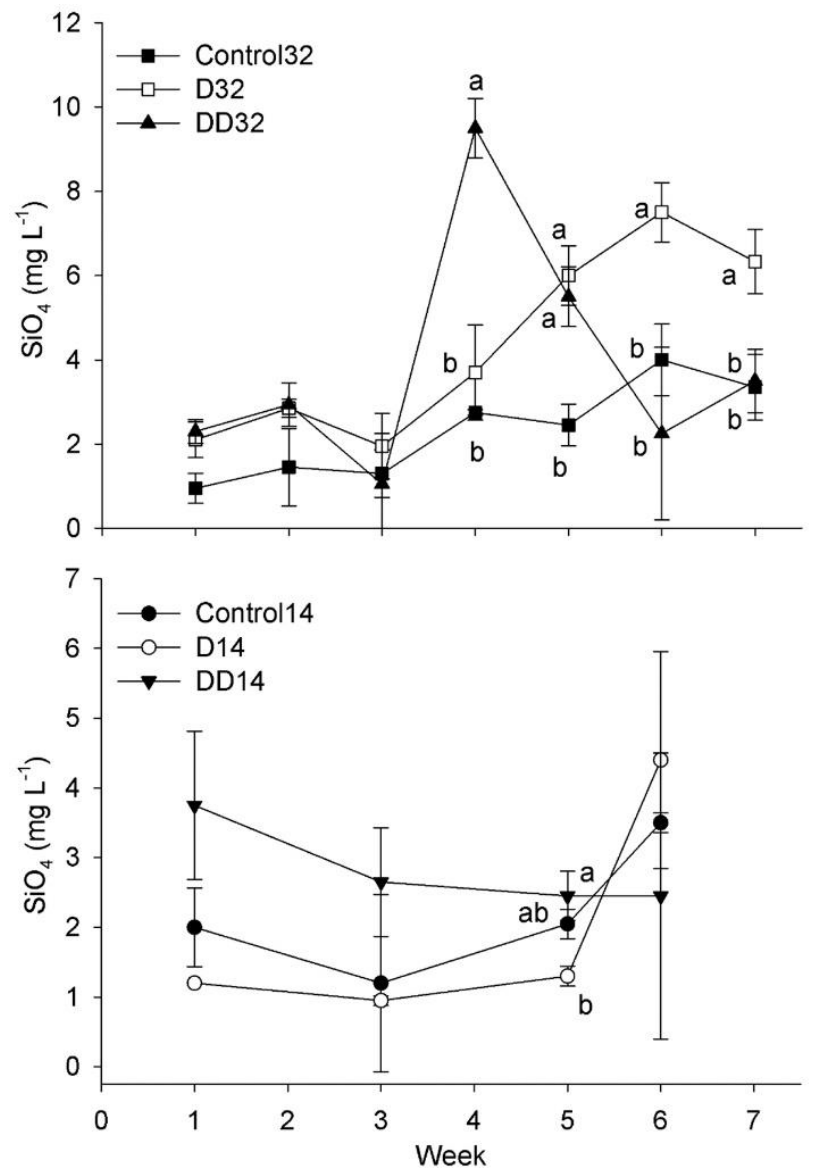

Figure 2. Mean variations of silicates $\left(\mathrm{SiO}_{4}\right)$ in different treatments at 32 and $14 \mathrm{~g} \mathrm{~L}^{-1}$ salinities conditions. Different superscript letters are significantly different $(P$ $<0.05)$.

Table 3. Growth performance and feed utilization of postlarvae of Penaeus vannamei cultivated in marine water $\left(32 \mathrm{~g} \mathrm{~L}^{-1}\right)$ with biofloc and diatomite. Data are means values \pm standard deviation. Control-32: biofloc in marine water; D32: biofloc with the addition of diatomite; DD32: biofloc with the addition of diatomite and diatoms Chaetoceros muelleri. WG: weight gain; SGR: specific growth rate; FCR: feed conversion rate. Values in the same row with different superscript letters are significantly different $(P<0.05)$.

\begin{tabular}{lccc}
\hline Parameter & Control-32 & \multicolumn{1}{c}{ D32 } & \multicolumn{1}{c}{ DD32 } \\
\hline Initial weight $\left(\times 10^{-3} \mathrm{~g}\right)$ & $7.5 \pm 0.5$ & $7.5 \pm 0.5$ & $7.5 \pm 0.5$ \\
Final weight $(\mathrm{g})$ & $3.36 \pm 0.7^{\mathrm{ab}}$ & $1.97 \pm 0.6^{\mathrm{b}}$ & $4.38 \pm 0.7^{\mathrm{a}}$ \\
$\mathrm{WG}(\mathrm{g})$ & $3.35 \pm 0.7^{\mathrm{ab}}$ & $1.96 \pm 0.6^{\mathrm{b}}$ & $4.37 \pm 0.7^{\mathrm{a}}$ \\
$\mathrm{SGR}\left(\% \mathrm{~d}^{-1}\right)$ & $13 \pm 0.4^{\mathrm{ab}}$ & $12 \pm 0.7^{\mathrm{b}}$ & $14 \pm 0.3^{\mathrm{a}}$ \\
FCR & $1.06 \pm 0.24$ & $1.02 \pm 0.10$ & $1.01 \pm 0.13$ \\
Final biomass $(\mathrm{g})$ & $903 \pm 247^{\mathrm{ab}}$ & $701 \pm 69^{\mathrm{b}}$ & $1,175 \pm 166^{\mathrm{a}}$ \\
Survival $(\%)$ & $85.4 \pm 7.1$ & $94.8 \pm 4.7$ & $85.3 \pm 5.6$ \\
\hline
\end{tabular}

that grows in BFT systems (Monroy-Dosta et al., 2013 ), and $\mathrm{SiO}_{4}$ is one of the essential nutrients for pro-
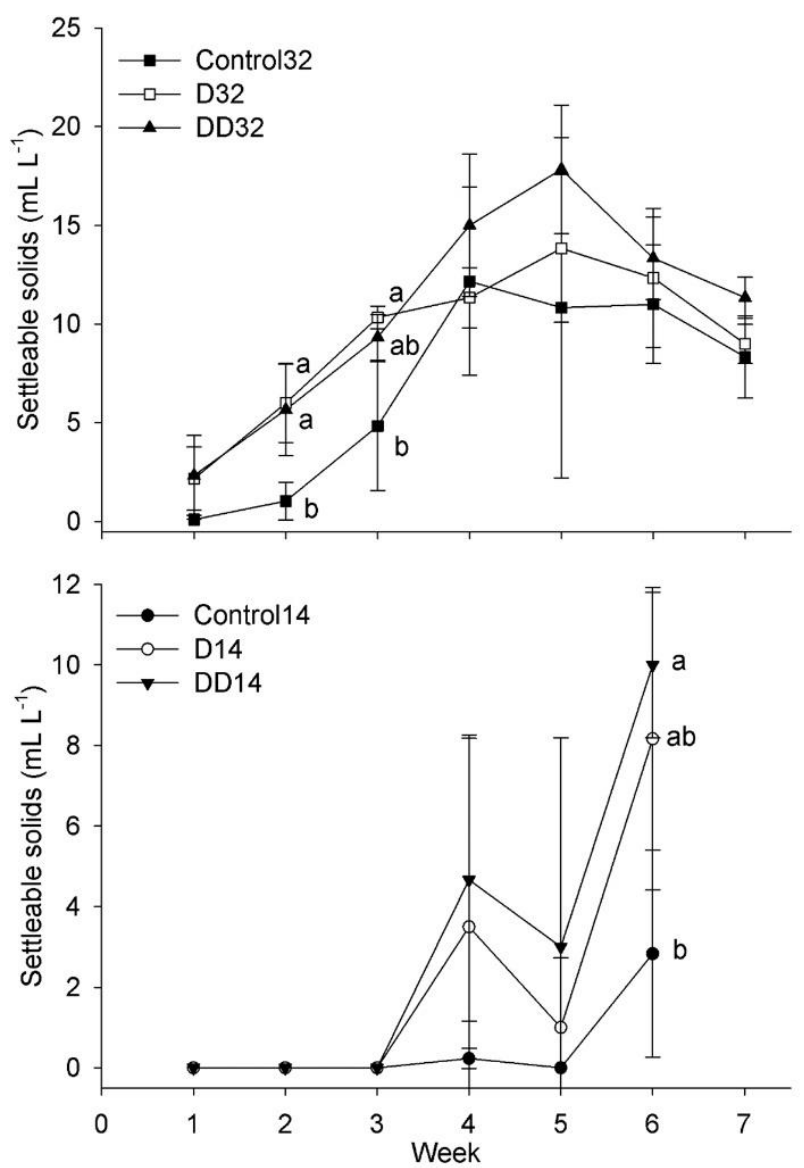

Figure 3. Mean variations of settleable solids in different treatments at 32 and $14 \mathrm{~g} \mathrm{~L}^{-1}$ salinities conditions. Different superscript letters are significantly different $(P<$ 0.05).

Table 4. Growth performance and feed utilization of juvenile of Penaeus vannamei cultivated in brackish water (14 $\left.\mathrm{g} \mathrm{L}^{-1}\right)$ with biofloc and diatomite. Data are means values \pm standard deviation. Control-14: biofloc in brackish water; D14: biofloc with the addition of diatomite; DD14: biofloc with the addition of diatomite and diatoms Chaetoceros muelleri. WG: weight gain; SGR: specific growth rate; FCR: feed conversion rate. Values in the same row with different superscript letters are significantly different $(P<0.05)$.

\begin{tabular}{lccc}
\hline Parameter & Control-14 & D14 & DD14 \\
\hline Initial weight $(\mathrm{g})$ & $1.42 \pm 0.45$ & $1.42 \pm 0.45$ & $1.42 \pm 0.45$ \\
Final weight $(\mathrm{g})$ & $9.4 \pm 0.9^{\mathrm{b}}$ & $11.4 \pm 0.5^{\mathrm{a}}$ & $10.8 \pm 0.3^{\mathrm{ab}}$ \\
$\mathrm{WG}(\mathrm{g})$ & $7.64 \pm 0.5^{\mathrm{b}}$ & $9.83 \pm 0.4^{\mathrm{a}}$ & $9.50 \pm 1.5^{\mathrm{ab}}$ \\
$\mathrm{SGR}\left(\% \mathrm{~d}^{-1}\right)$ & $3.86 \pm 0.18^{\mathrm{b}}$ & $4.25 \pm 0.08^{\mathrm{a}}$ & $4.24 \pm 0.22^{\mathrm{ab}}$ \\
FCR & $1.49 \pm 0.11^{\mathrm{a}}$ & $1.16 \pm 0.09^{\mathrm{b}}$ & $1.30 \pm 0.01^{\mathrm{ab}}$ \\
Final biomass $(\mathrm{g})$ & $1,517 \pm 135^{\mathrm{b}}$ & $2,052 \pm 150^{\mathrm{a}}$ & $1,801 \pm 478^{\mathrm{ab}}$ \\
Survival $(\%)$ & $81.3 \pm 14.3$ & $90 \pm 7.6$ & $88.5 \pm 2.8$ \\
\hline
\end{tabular}

per algal growth, especially for diatoms, as well as in freshwater systems with biofloc (Widanarni et al., 2012). 
Table 5. Proximate composition (wet weight \%) of periphyton, biofloc and whole-body shrimp cultivated in marine water $\left(32 \mathrm{~g} \mathrm{~L}^{-1}\right)$ with biofloc and diatomite. Data are means values \pm standard deviation. Control-32: biofloc in marine water; D32: biofloc with the addition of diatomite; DD32: biofloc with the addition of diatomite and diatoms Chaetoceros muelleri. Values in the same row with different superscript letters are significantly different $(P<0.05)$.

\begin{tabular}{lccccc}
\hline & \multicolumn{5}{c}{ Proximate composition (wet weight \%) } \\
\cline { 2 - 6 } & Moisture & Crude protein & Crude lipids & Ash & Dry matter \\
\hline Periphyton & & & & & \\
Control-32 & $93.1 \pm 2.1$ & $1.28 \pm 0.54$ & $0.78 \pm 0.12$ & $2.96 \pm 0.45$ & $6.92 \pm 2.2$ \\
D32 & $89.4 \pm 4.3$ & $2.04 \pm 1.08$ & $0.77 \pm 0.36$ & $4.91 \pm 1.60$ & $10.6 \pm 4.3$ \\
DD32 & $86.5 \pm 9.7$ & $1.86 \pm 1.35$ & $0.99 \pm 0.69$ & $4.25 \pm 2.76$ & $13.5 \pm 9.7$ \\
Biofloc & & & & & \\
Control-32 & $85.7 \pm 0.5$ & $3.56 \pm 0.14^{\mathrm{a}}$ & $0.89 \pm 0.21$ & $6.66 \pm 1.35$ & $14.3 \pm 0.5$ \\
D32 & $85.8 \pm 1.6$ & $2.29 \pm 0.24^{\mathrm{b}}$ & $0.87 \pm 0.23$ & $6.70 \pm 0.57$ & $14.2 \pm 1.6$ \\
DD32 & $84.5 \pm 1.5$ & $3.40 \pm 0.53^{\mathrm{a}}$ & $0.99 \pm 0.19$ & $7.20 \pm 0.91$ & $15.5 \pm 1.5$ \\
Shrimps & & & & & \\
Control-32 & $79.6 \pm 2.2$ & $15.4 \pm 1.4$ & $3.25 \pm 0.43$ & $2.66 \pm 0.25$ & $20.4 \pm 2.2$ \\
D32 & $83.1 \pm 2.9$ & $12.7 \pm 2.6$ & $2.43 \pm 0.52$ & $2.37 \pm 0.23$ & $16.9 \pm 2.9$ \\
DD32 & $81.3 \pm 1.0$ & $14.1 \pm 0.9$ & $2.42 \pm 0.06$ & $2.44 \pm 0.22$ & $18.7 \pm 1.0$ \\
\hline
\end{tabular}

Table 6. Proximate composition (wet weight \%) of periphyton, biofloc and shrimp cultivated in brackish water $\left(14 \mathrm{~g} \mathrm{~L}^{-1}\right)$ with biofloc and diatomite. Data are means values \pm standard deviation. Control-14: biofloc in brackish water; D14: biofloc with the addition of diatomite; DD14: biofloc with the addition of diatomite and diatoms Chaetoceros muelleri. *Values with no standard deviation are the median from Kruskal-Wallis analysis. Values in the same column with different superscript letters are significantly different $(P<0.05)$.

\begin{tabular}{lccccc}
\hline & \multicolumn{5}{c}{ Proximate composition (wet weight \%) } \\
\cline { 2 - 6 } & Moisture* & Crude protein* & Crude lipids & Ash & Dry matter* \\
\hline Periphyton & & & & & \\
Control-14 & 92.4 & 2.25 & $0.57 \pm 0.16$ & $2.15 \pm 0.46^{\mathrm{b}}$ & 7.63 \\
D14 & 90.2 & 2.63 & $0.54 \pm 0.02$ & $4.43 \pm 0.02^{\mathrm{a}}$ & 9.84 \\
DD14 & 90.7 & 2.60 & $0.56 \pm 0.06$ & $4.22 \pm 0.51^{\mathrm{a}}$ & 9.31 \\
Biofloc & & & & & \\
Control-14 & $91.7 \pm 0.3$ & 3.56 & $0.70 \pm 0.10$ & $2.25 \pm 0.13^{\mathrm{b}}$ & $8.32 \pm 0.27$ \\
D14 & $90.6 \pm 0.4$ & 2.28 & $1.00 \pm 0.48$ & $4.26 \pm 0.16^{\mathrm{a}}$ & $9.37 \pm 0.44$ \\
DD14 & $90.6 \pm 0.1$ & 2.51 & $0.69 \pm 0.13$ & $4.30 \pm 0.22^{\mathrm{a}}$ & $9.39 \pm 0.11$ \\
Shrimps & & & & & \\
Control-14 & $81.3 \pm 2.1$ & $12.6 \pm 1.7$ & $2.84 \pm 0.35$ & $1.84 \pm 0.26$ & $18.7 \pm 2.1$ \\
D14 & $82.2 \pm 0.5$ & $12.1 \pm 0.2$ & $2.59 \pm 0.24$ & $1.74 \pm 0.05$ & $17.8 \pm 0.5$ \\
DD14 & $82.3 \pm 1.6$ & $11.6 \pm 0.8$ & $2.58 \pm 0.41$ & $1.81 \pm 0.21$ & $17.7 \pm 1.6$ \\
\hline
\end{tabular}

Siliceous compounds have been used in an attempt to increase dissolved silicate levels in the water. Nieves et al. (2000, 2002) and Leal et al. (2003) found a positive effect of zeolites to improve on the cell doubling time of diatoms and in the durability of cultures; however, zeolites are characterized by poor solubility and low silica release. Thus, the use of other sources of silica of higher availability has been recommended, such as diatomite and its derivatives (Xie et al., 2014). In our bioassay conducted in seawater showed the highest $\mathrm{SiO}_{4}$ levels only in treatments where diatomite (but no diatoms) was added.
Higher survival levels are directly related to appropriate culture conditions, and nitrogenous wastes levels (particularly TAN and nitrites) have been considered to be the main limiting factors for shrimp survival (Liu et al., 2014). In this study, non-ionized TAN levels (toxic moiety) were 0.04 and $0.07 \mathrm{mg} \mathrm{L}^{-1}$ at salinities of 32 and $14 \mathrm{~g} \mathrm{~L}^{-1}$, respectively; slightly above the recommended maximum optimal levels $\left(\leq 0.03 \mathrm{mg} \mathrm{L}^{-1}\right.$; VanWyk \& Scarpa, 1999), while $\mathrm{NO}_{2}-\mathrm{N}$ levels were within acceptable limits $\left(<1 \mathrm{mg} \mathrm{L}^{-1}\right)$ for $P$. vannamei (VanWyk \& Scarpa, 1999). Similarly, $\mathrm{NO}_{3}-\mathrm{N}$ levels were below the maximum recommended levels (177 $\mathrm{mg} \mathrm{L}^{-1}$ ) for this species maintained in biofloc without 
water exchange. On the other hand, the higher values of $\mathrm{NO}_{3}-\mathrm{N}$ levels recorded at a salinity of $14 \mathrm{~g} \mathrm{~L}^{-1}$ (maximum $15 \mathrm{mg} \mathrm{L}^{-1}$ ) respect those recorded in the seawater culture (maximum $3 \mathrm{mg} \mathrm{L}^{-1}$ ) suggest that the use of mature biofloc from $\mathrm{E} 1$ to $\mathrm{E} 2$ improved the nitrification rate in the second bioassay.

As regards to growth parameters, in the experiment with shrimp post larvae cultured in seawater (E1), do not significant differences were found in the final weight, WG, SGR and final biomass between the treatment DD32 (diatomite plus diatom C. muelleri) and Control-32, due to the fact that BFT systems, by themselves, promote the growth of white shrimp postlarvae and juvenile (Xu \& Pan, 2012; Xu et al., 2012; Schveitzer et al., 2013; Emerenciano et al., 2013a; Lara et al., 2017) by improving their digestive capacity (Xu $\&$ Pan, 2012a) and providing nutrients such as proteins and lipids in addition to those in the balanced feed (Khatoon et al., 2016). However, in the brackish water culture (E2), the addition of diatomite fostered a significant increase in juvenile shrimp growth, measured as final weight, WG, SGR and final biomass compared to Control-14 without diatomite. BecerraDorame et al. (2012) report that systems with autotrophic biofloc (dominated by microalgae) provide higher lipid and lower protein contents, compared to heterotrophic systems (dominated by bacteria). Separately, for culturing juvenile $P$. vannamei, it has been recommended the use of mixed biofloc (dominated by microalgae and autotroph bacteria), since its use increases production yield while lowering production costs due to less consumption of formulated feed and oxygen (Xu et al., 2016). In the present study, the lipid and protein composition of both periphyton and biofloc were not found significant different into experiments. So, the improved growth of shrimp has been related to the diatomite addition, which promoted a higher volume of flocs in the tanks to be eaten by shrimps.

\section{CONCLUSIONS}

Diatomite addition to BFT cultures improved growth performance and feed efficiency of white shrimp postlarvae and juveniles reared in brackish water under intensive farming. Further research is needed to understand the effects of diatomite addition on the population dynamics of microalgae and bacteria present in mixotrophic and autotrophic for Penaeus vannamei culture.

\section{ACKNOWLEDGMENTS}

This study was supported by Diatomix, S. de R.L. de C.V., Consejo Nacional de Ciencia y Tecnología
(CONACYT), Project CB 2015/253151 and Universidad Autónoma de Sinaloa, Project PROFAPI2015/ 033. Thanks to the students of the Faculty of Marine Sciences for their hardworking support during the assays. Also, the authors thank María Elena SánchezSalazar for her editorial work in English.

\section{REFERENCES}

Association of Official Agricultural Chemists (AOAC). 2000. Official methods of analysis of AOAC International. Association of Official Agricultural Chemists International, Maryland.

Avnimelech, Y. 2007. Feeding with microbial flocs by tilapia in minimal discharge bioflocs technology ponds. Aquaculture, 264: 140-147. doi: 10.1016/ j.aquaculture.2006.11.025

Becerra-Dorame, M., Martínez-Porchas, M., MartínezCórdova, L.R., Rivas-Vega, M.E., Lopez-Elias, J.A. \& Porchas-Cornejo, M.A. 2012. Production response and digestive enzymatic activity of the Pacific white shrimp Litopenaeus vannamei (Boone, 1931) intensively pregrown in microbial heterotrophic and autotrophic-based systems. Scientific World Journal, 723654. doi: $10.1100 / 2012 / 723654$

Bossier, P. \& Ekasari, J. 2017. Biofloc technology application in aquaculture to support sustainable development goals. Microbial Technology, 10(5): 10121016.

Da Silva, K.R., Wasielesky Jr., W. \& Abreu, P.C. 2013. Nitrogen and phosphorus dynamics in the biofloc production of the Pacific white shrimp, Litopenaeus vannamei. Journal of the World Aquaculture Society, 44: 30-41. doi: 10.1111/jwas.12009

Ekasari, J., Angela, D., Waluyo, S.H., Bachtiar, T., Surawidjaja, E.H., Bossier, P. \& De Schryver, P. 2014. The size of biofloc determines the nutritional composition and the nitrogen recovery by aquaculture animals. Aquaculture, 426-427: 105-111. doi:10.1016/ j.aquaculture.2014.01.023

Emerenciano, M., Cuzon, G., Paredes, A. \& Gaxiola, G. 2013a. Evaluation of biofloc technology in pink shrimp Farfantepenaeus duorarum culture: growth performance, water quality, microorganisms profile and proximate analysis of biofloc. Aquaculture International, 21(6): 1381-1394. doi: 10.1007/s10499013-9640-y

Emerenciano, M., Gaxiola, G. \& Cuzon, G. $2013 b$. Biofloc technology (BFT): a review for aquaculture application and animal food industry. In: Matovic, M.D. (Ed.). Biomass now -cultivation and utilization. Queen's University, Belfast, pp. 301-328.

Folch, J., Lees, M. \& Sloane-Stanley, G.H. 1957. A simple method for the isolation and purification of total lipids 
from animal tissues. Journal of Biological Chemistry, 226: 497-509.

Guillaume, J., Kaushik, S., Bergot, P. \& Métailler, R. 2004. Nutrition and feeding of fish and crustaceans. Mundi Prensa, Madrid.

Hargreaves, J.A. 2013. Biofloc production systems for aquaculture. Southern Regional Aquaculture Center, 4503: 1-12.

Khatoon, H., Banerjee, S., Guan-Yuan, G.T., Haris, N., Ikhwanuddin, M., Ambak, A. \& Endut, A. 2016. Biofloc as a potential natural feed for shrimp postlarvae. International Biodeterioration and Biodegradation, 113: 304-309. doi: 10.1016/j.ibiod.2016.04. 006

Kumar, V.S., Pandey, P.K., Anand, T., Bhuvaneswari, G.R., Dhinakaran, A. \& Kumar, S. 2018. Biofloc improves water, effluent quality, and growth parameters of Penaeus vannamei in an intensive culture system. Journal of Environmental Management, 215: 206-215.

Lara, G., Krummenauer, D., Abreu, P.C., Poersch, L.H. \& Wasielesky Jr., W. 2017. The use of different aerators on Litopenaeus vannamei biofloc culture system: effects on water quality, shrimp growth, and biofloc composition. Aquaculture International, 25(1): 147162. doi: 10.1007/s10499-016-0019-8.

Leal, S., Delgado, G., Rodríguez, G., López-Ruiz, J., Alfonso, E. \& Nodas, E. 2003. Crecimiento de microalgas marinas con diferentes productos zeolíticos. Revista de Investigaciones Marinas, 24(1): 57-62.

Liu, L., Hu, Z., Dai, X. \& Avnimelech, Y. 2014. Effects of addition of maize starch on the yield, water quality, and formation of bioflocs in an integrated shrimp culture system. Aquaculture, 418-419: 79-86. doi: 10.1016/j.aquaculture.2013.10.005

Magnotti, C., Lopes, R., Derner, R. \& Vinatea, L. 2016. Using residual water from a marine shrimp farming BFT system. Part I: Nutrient removal and marine microalgae biomass production. Aquaculture Research, 47(8): 2435-2443. doi: 10.1111/are.12720

Maicá, P.F., De Borba, M.R., Martins, T.G. \& Wasielesky Jr., W. 2014. Effect of salinity on performance and body composition of Pacific white shrimp juveniles reared in a super-intensive system. Revista Brasileira de Zootecnia, 43(7): 343-350. doi: 10.1590/S151635982014000700001

Marinho, Y.F., Brito, L.O., Silva Campos, C.V.F.D., Severi, W., Andrade, H.A. \& Galvez, A.O. 2017. Effect of the addition of Chaetoceros calcitrans, Navicula sp., and Phaeodactylum tricornutum (diatoms) on phytoplankton composition and growth of Litopenaeus vannamei (Boone) post-larvae reared in a biofloc system. Aquaculture Research, 48(8): 4155-4164. doi: 10.1111/are.13235

Martínez-Córdova, L.R., Emerenciano, M., MirandaBaeza, A. \& Martínez-Porchas, M. 2015. Microbialbased systems for aquaculture of fish and shrimp: an updated review. Reviews in Aquaculture, 7(2): 131148. doi: 10.1111/raq. 12058

Monroy-Dosta, M.D.C., Lara-Andrade, D., Castro-Mejía, J., Castro-Mejía, G. \& Coelho-Emerenciano, M.G. 2013. Composición y abundancia de comunidades microbianas asociadas al biofloc en un cultivo de tilapia. Revista de Biología Marina y Oceanografía, 48(3): 511-520. doi: 10.4067/S0718-19572013000 300009

Moreno-Arias, A., López-Elías, J.A., Miranda-Baeza, A., Rivas-Vega, M.E., Martínez-Córdova, L.R. \& Ramírez-Suárez, J.C. 2016. Replacement of fishmeal by vegetable meal mix in the diets of Litopenaeus vannamei reared in low salinity biofloc system: effect on digestive enzymatic activity. Aquaculture Nutrition, 23(2): 1-10. doi: 10.1111/anu.12384

Nieves, M., Voltolina, D., López-Ruiz, J., Cisneros, M.A. \& Piña, P. 2000. Cultivo de microalgas marinas con medios enriquecidos con productos de naturaleza zeolítica. Hidrobiológica, 10(1): 1-6.

Nieves, M., Voltolina, D., Medina, A., Piña, P. \& Ruiz, J.L. 2002. Zeolites and diatom growth. Aquaculture Research, 33(1): 75-79. doi: 10.1046/j.1355-557X. 2001.00646.x

Ponce-Palafox, J.T., Pavia, Á.A., Mendoza-López, D.G., Arredondo-Figueroa, J.L., Lango-Reynoso, F., Castañeda-Chávez, M.D.R., Esparza-Leal, H., RuizLuna, A., Páez-Ozuna, F., Castillo-Vargasmachuca, S.G. \& Peraza-Gómez, V. 2019. Response surface analysis of temperature-salinity interaction effects on water quality, growth, and survival of shrimp Penaeus vannamei postlarvae raised in biofloc intensive nursery production. Aquaculture, 503: 312-321. doi: 10.1016/j.aquaculture.2019.01.020

Ray, A.J. \& Lotz, J.M. 2017. Comparing salinities of 10, 20 , and $30 \%$ in intensive, commercial-scale biofloc shrimp (Litopenaeus vannamei) production systems. Aquaculture, 476: 29-36. doi: 10.1016/j.aquaculture. 2017.03.047

Ray, A.J., Dillon, K.S. \& Lotz, J.M. 2011. Water quality dynamics and shrimp (Litopenaeus vannamei) production in intensive, mesohaline culture systems with two levels of biofloc management. Aquaculture Engineering, 45: 127-136. doi: 10.1016/j.aquaeng.2011.09.001

Silapajarn, O., Silapajarn, K. \& Boyd, C.E. 2006. Evaluation of zeolite products used for aquaculture in Thailand. Journal of the World Aquaculture Society, 
37(1): 136-138. doi: 10.1111/j.1749-7345.2006.000 18. $\mathrm{x}$

Schveitzer, R., Arantes, R., Cosódio, P.F.S., Espírito Santo, C.M., Arana, L.V., Seiffer, W.Q. \& Andreatta, E.R. 2013. Effect of different biofloc levels on microbial activity, water quality, and performance of Litopenaeus vannamei in a tank system operated with no water exchange. Aquaculture Engineering, 56: 5970. doi: 10.1016/j.aquaeng.2013.04.006

Van Wyk, P. \& Scarpa, J. 1999. Water quality requirements and management. In: Van Wyk, P. (Ed.). Farming marine shrimp in recirculating freshwater systems. Florida Department of Agriculture and Consumer Services, Florida, pp. 128-138.

Windanari, W., Ekasari, J. \& Maryam, S. 2012. Evaluation of biofloc technology application on water quality and production performance of red tilapia Oreochromis sp. cultured at different stocking densities. Hayati Journal of Biosciences, 19(2): 73-80. doi: 10.4308/hjb.19.2.73

Xie, F., Wu, F., Liu, G., Mu, Y., Feng, C., Wang, H. \& Giesy, J.P. 2014. Removal of phosphate from eutrophic lakes through adsorption by in situ formation of magnesium hydroxide from diatomite. Environmental Science and Technology, 48(1): 582-590. doi: $10.1021 /$ es4037379

Received: 6 June 2019; Accepted: 3 August 2019
Xu, W.J. \& Pan, L.Q. 2012. Effects of bioflocs on growth performance, digestive enzyme activity, and body composition of juvenile Litopenaeus vannamei in zero-water exchange tanks manipulating $\mathrm{C} / \mathrm{N}$ ratio in feed. Aquaculture, 356-357: 147-152. doi: 10.1016/ j.aquaculture.2012.05.022

Xu, W.J., Morris, T.C. \& Samocha, T.M. 2016. Effects of $\mathrm{C} / \mathrm{N}$ ratio on biofloc development, water quality, and performance of Litopenaeus vannamei juveniles in a biofloc-based, high-density, zero-exchange, outdoor tank system. Aquaculture, 453: 169-175. doi: 10.1016/ j.aquaculture.2015.11.021

Xu, W.J., Pan, L.Q., Zhao, D.H. \& Huang, J. 2012. Preliminary investigation into the contribution of bioflocs on protein nutrition of Litopenaeus vannamei fed with different dietary protein levels in zero-water exchange culture tanks. Aquaculture, 350-353: 147153. doi: $10.1016 /$ j.aquaculture.2012.04.003

Zar, J.H. 1999. Biostatistical analysis. Prentice-Hall, New Jersey.

Zhou, L. \& Boyd, C.E. 2014. Total ammonia nitrogen removal from aqueous solutions by the natural zeolite, mordenite: a laboratory test and experimental study. Aquaculture, 432: 252-257. doi: 10.1016/j.aquaculture.2014.05.019 